\title{
Effects of Infectious Diseases on Population Dynamics of Marine Organisms in Chesapeake Bay
}

\author{
Jerelle A. Jesse ${ }^{1} \cdot$ M. Victoria Agnew ${ }^{2} \cdot$ Kohma Arai $^{1} \cdot$ C. Taylor Armstrong ${ }^{3} \cdot$ Shannon M. Hood $^{4} \cdot$ Mariah L. Kachmar $^{2}$ • \\ Jessie T. Long ${ }^{4} \cdot$ Alexandra J. McCarty ${ }^{4} \cdot$ Morgan O. Ross $^{4} \cdot$ Kasondra D. Rubalcava $^{5} \cdot$ Jacob Shaner $^{6} \cdot$ Sakura Tanaka $^{2}$. \\ Lindsay Wood ${ }^{7}$. Eric J. Schott ${ }^{3} \cdot$ Michael J. Wilberg ${ }^{1}$
}

Received: 6 March 2020 / Revised: 3 February 2021 / Accepted: 6 February 2021 / Published online: 24 March 2021

(C) The Author(s) 2021

\begin{abstract}
Diseases are important drivers of population and ecosystem dynamics. This review synthesizes the effects of infectious diseases on the population dynamics of nine species of marine organisms in the Chesapeake Bay. Diseases generally caused increases in mortality and decreases in growth and reproduction. Effects of diseases on eastern oyster (Crassostrea virginica) appear to be low in the 2000s compared to effects in the 1980s-1990s. However, the effects of disease were not well monitored for most of the diseases in marine organisms of the Chesapeake Bay, and few studies considered effects on growth and reproduction. Climate change and other anthropogenic effects are expected to alter host-pathogen dynamics, with diseases of some species expected to worsen under predicted future conditions (e.g., increased temperature). Additional study of disease prevalence, drivers of disease, and effects on population dynamics could improve fisheries management and forecasting of climate change effects on marine organisms in the Chesapeake Bay.
\end{abstract}

Keywords Host pathogen $\cdot$ Mycobacteriosis $\cdot$ Eastern oyster $\cdot$ Blue crab $\cdot$ Eelgrass $\cdot$ Wasting disease

\section{Introduction}

Infectious diseases can have substantial effects on population dynamics and communities of marine organisms (Andrews

Communicated by Kenneth L. Heck

Michael J. Wilberg

wilberg@umces.edu

1 Chesapeake Biological Laboratory, University of Maryland Center for Environmental Science, Solomons, MD 20688, USA

2 Institute of Marine and Environmental Technology, University of Maryland Baltimore County, Baltimore, MD 21202, USA

3 Institute of Marine and Environmental Technology, University of Maryland Center for Environmental Science, Baltimore, MD 21202, USA

4 Horn Point Laboratory, University of Maryland Center for Environmental Science, Cambridge, MD 21613, USA

5 University of Maryland Eastern Shore, Princess Anne, MD 21853 , USA

6 Maryland Department of Natural Resources, Cooperative Oxford Laboratory, Oxford, MD 21654, USA

7 University of Maryland College Park, College Park, MD 20742, USA
1979; Muehlstein et al. 1991; Groner et al. 2018b). For this paper, infectious disease is defined as a disease caused by bacterial, fungal, viral, or parasitic infections that can be transmitted from one individual to another (simply referred to as diseases hereafter). Diseases can affect population dynamics by altering mortality, growth, and reproduction (Fig. 1). The most studied effect of disease is increased mortality, which causes decreased abundance of a population. Disease can have negative effects on growth and reproduction. For example, a population with a sustained low disease prevalence and severity should experience low population-level mortality rates, ${ }^{1}$ high growth, and reproduction sufficient to replace the individuals lost from mortality (Fig. 1a). Alternatively, high levels of a lethal disease (Fig. 1b) can increase mortality rates, decrease growth, and decrease reproduction resulting in a smaller population size than the low disease case. These population dynamic effects can interact with each other and can be affected by other stressors. Thus, the effects of disease on a population are complicated and likely change over time.

Diseases can have important effects on fisheries. For example, MSX, caused by the protozoan parasite Haplosporidium

\footnotetext{
${ }^{1}$ Throughout the manuscript we use the population definition of mortalitythe fraction of the population that dies during a specified timeframe.
} 

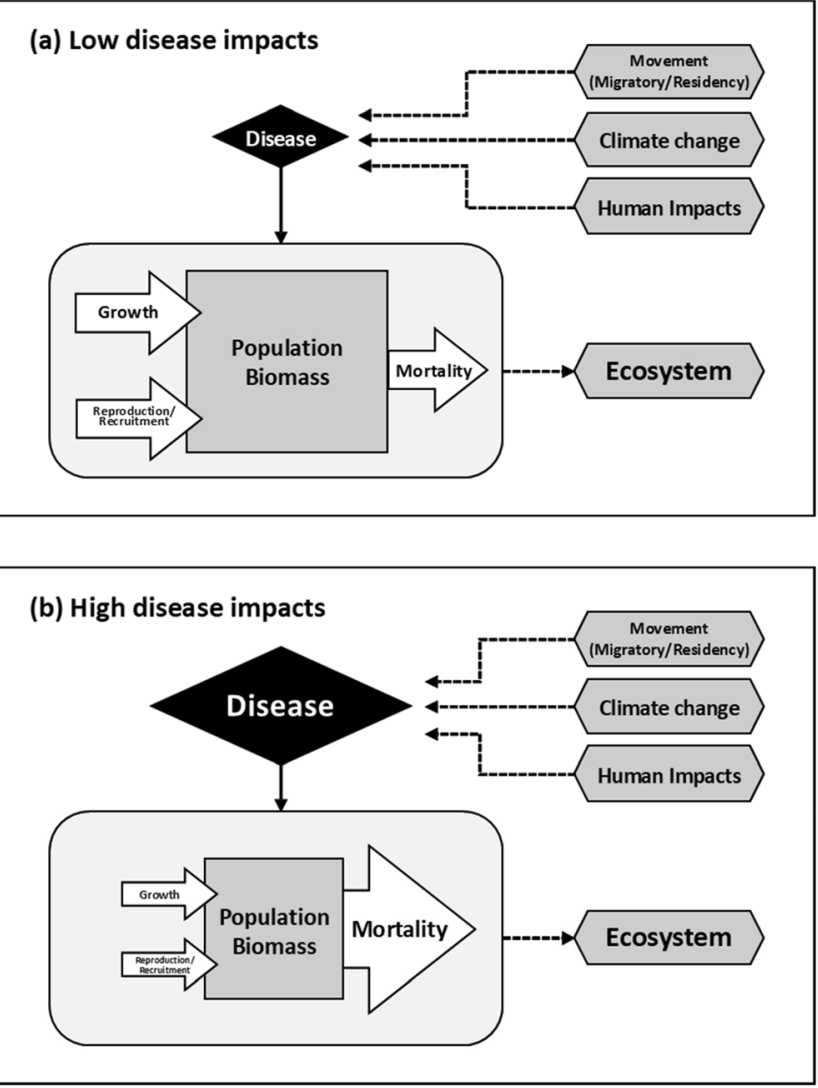

Fig. 1 Conceptual diagram illustrating population biomass change under two extreme scenarios, a low disease impacts and $\mathbf{b}$ high disease impacts. Under low disease prevalence and pathogenicity (a), increase in population biomass from growth and reproduction is balanced by the decrease from mortality. Under high disease prevalence and pathogenicity (b), biomass increase from growth and reproduction will be reduced, and total mortality will be elevated. Total population biomass under high disease impacts will therefore be smaller than in the low disease impacts scenario. Effects of disease on growth, reproduction, and mortality can change the population biomass and have impacts on the whole ecosystem. Disease prevalence and pathogenicity are affected by movement of individuals in the population, climate change, and human impacts

nelsoni, resulted in the collapse of the fishery for eastern oyster (Crassostrea virginica) in Delaware Bay during the 1950s (Ford and Bushek 2012). The Chesapeake Bay is important for commercial and recreational fisheries with the total dockside commercial revenue of key species at just under $\$ 300$ million in 2016 (National Marine Fisheries Service 2018). The Chesapeake Bay also serves as spawning and nursery habitat for many species in the western Atlantic Ocean. Therefore, it is essential to understand the effects of diseases that affect the population dynamics of marine species in the Chesapeake Bay.

The objective of this review is to describe the effects of disease on the population dynamics of nine species of marine organisms in Chesapeake Bay (Table 1). The organisms included in this review are some of the most ecologically and economically important species in the Bay. The review highlights the gaps in our knowledge about how diseases affect populations and is organized by disease effects on population dynamics processes (mortality, growth, and reproduction). Furthermore, we discuss how external factors, such as climate change and aquaculture, may alter the effects of diseases on these processes. Information on transmission of diseases was not included because there are knowledge gaps regarding transmission for most of the included species.

\section{Population Dynamics}

\section{Mortality}

Mortality is the most well-studied effect of diseases of Chesapeake Bay marine organisms. Disease-driven mortality affects species throughout Chesapeake Bay, from the benthic environment to the pelagic zone (Table 1). While some diseases affect multiple species (Stine et al. 2010), many only affect a single species or family of species within Chesapeake Bay (e.g., Muehlstein et al. 1991; Ragone Calvo et al. 2003b). Although well-researched disease-driven mortalities are documented for many economically important species (Ragone Calvo et al. 2003b; Hoenig et al. 2017), disease may affect other species that are not commonly monitored. In addition, mortality is more easily observed in some species than others (e.g., fish kills or gaping oysters; Ford et al. 2006; Gauthier et al. 2008). Therefore, it is likely that some diseases (or perhaps many) have not yet been prioritized or studied. Prevalence of a disease and individual-level mortality are necessary to understand the population level impacts of disease, but often disease dynamics are studied at small spatial or temporal scales which inhibits the understanding of full population effects (Table 2). In the Chesapeake Bay, striped bass and oyster diseases are well studied at the population level, but the effects of disease on the population are not well studied for other species.

Striped bass (Morone saxatilis) in the Chesapeake Bay are affected by mycobacteriosis, a chronic, progressive disease which results in internal granulomatous inflammation and external ulcerative lesions (Jacobs et al. 2009). Mycobacteriosis was first detected in the population in 1997 and correlates with an increase in natural mortality in the Chesapeake Bay according to tagging estimates (Northeast Fisheries Science Center 2019). Prevalence of mycobacteriosis can vary among years and locations and can exceed 60\% (Cardinal 2001; Gauthier et al. 2008; Hoenig et al. 2017; Groner et al. 2018b). The mortality of striped bass increases with increasing disease severity, with moderately and severely diseased individuals having $16 \%$ and $46 \%$ year $^{-1}$ higher mortality relative to healthy fish (Hoenig et al. 2017). Mortality among severely diseased striped bass is especially high, with average mortality from 56 to $87 \%$ year $^{-1}$ (Groner et al. 2018b). At the population-level, 

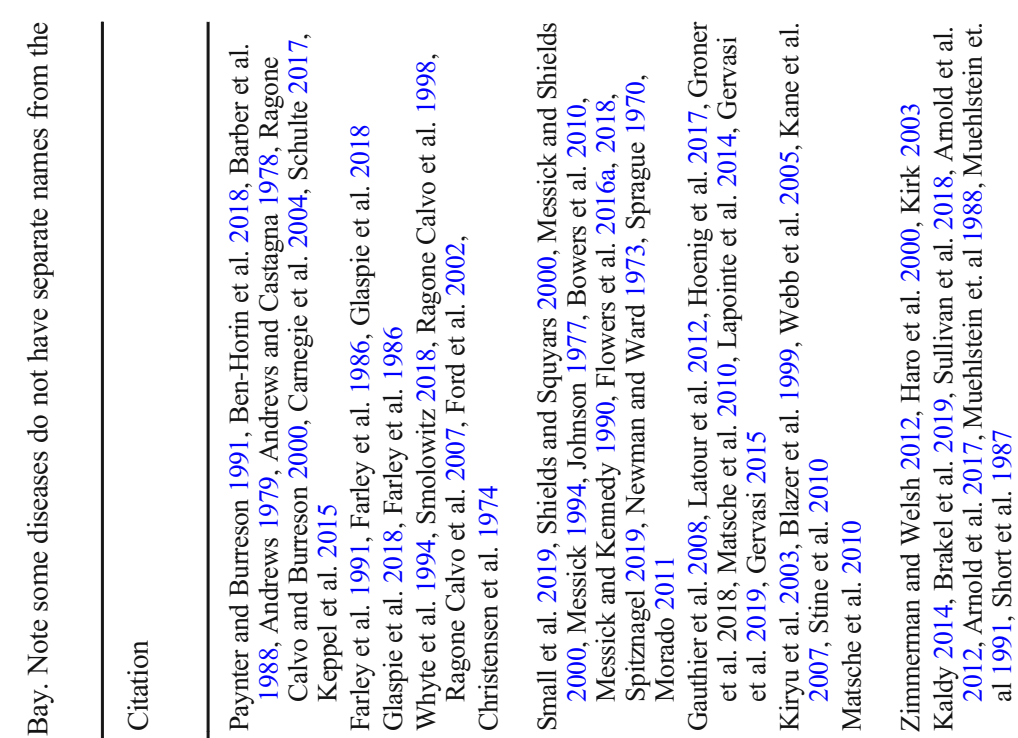

हैँ

峁

를
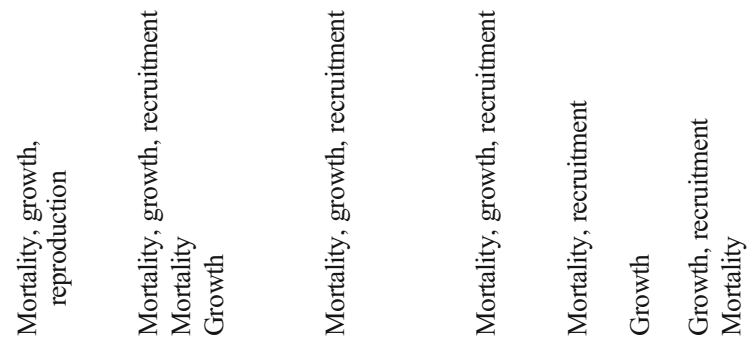

总

矛

敢

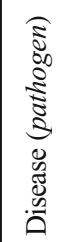

岁

资

ถิํํำ

吾谓

岁:

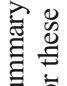

竞茫

㰴量
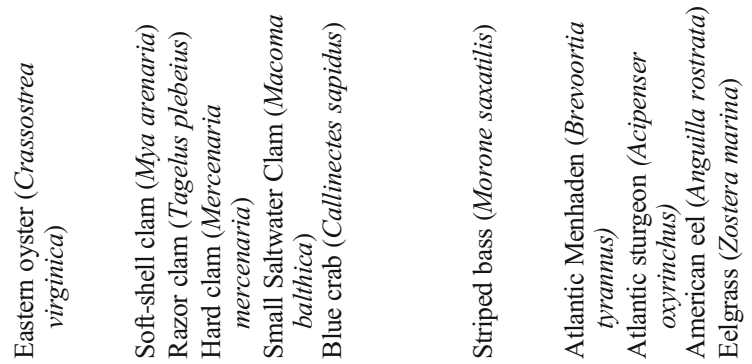
Table 2 Studies included in review by population dynamic effect including information on type of study and location of study

\begin{tabular}{|c|c|c|}
\hline Citation & Study type & Study location \\
\hline \multicolumn{3}{|l|}{ Mortality } \\
\hline Hoenig et al. 2017 & Field & Chesapeake Bay (MD and VA) \\
\hline Cardinal 2001 & Field & Chesapeake Bay (VA) \\
\hline Gauthier et al. 2008 & Field & Chesapeake Bay (MD and VA) \\
\hline Groner et al. $2018 b$ & Field & Chesapeake Bay (VA) \\
\hline Blazer et al. 1999 & Field & Chesapeake Bay (MD and VA) \\
\hline Kiryu et al. 2003 & Experiments & Chesapeake Bay (MD and VA) \\
\hline Webb et al. 2005 & Field & Chesapeake Bay (VA) \\
\hline Andrews et al. 1962 & Field & Chesapeake Bay and coastal bays (VA) \\
\hline Andrews and Castagna 1978 & Field & Chesapeake Bay to Delaware Bay \\
\hline Ragone Calvo et al. 2003b & Field & Chesapeake Bay (VA) \\
\hline Southworth et al. 2010 & Field & Chesapeake Bay (VA) \\
\hline Tarnowski 2019 & Field & Chesapeake Bay (MD) \\
\hline Ragone Calvo and Burreson & Field & Chesapeake Bay (VA) \\
\hline Carnegie et al. 2004 & Field & Chesapeake Bay (VA) \\
\hline Ford and Bushek 2012 & Field & Delaware Bay \\
\hline McCollough et al. 2007 & Field & Chesapeake Bay (MD) \\
\hline Paynter and Burreson 1991 & Field & Chesapeake Bay (MD and VA) \\
\hline Reece et al. 2008 & Field & Chesapeake Bay (MD and VA) \\
\hline Bushek and Ford 2016 & Field & Delaware Bay \\
\hline Dungan et al. 2002 & Field & Chesapeake Bay (MD) \\
\hline Farley et al. 1991 & Field & Chesapeake Bay (MD) \\
\hline Farley et al. 1986 & Field & Chesapeake Bay (MD) \\
\hline Johnson 1977 & Field and experiments & Chincoteague Bay, VA \\
\hline Newman and Ward 1973 & Field & Chincoteague Bay, VA \\
\hline Messick and Shields 2000 & Field & Chesapeake Bay and coastal bays (MD and VA) \\
\hline Shields and Squyars 2000 & Experiments & Chesapeake Bay (MD and VA) \\
\hline Bowers et al. 2010 & Field & Chesapeake Bay (MD) \\
\hline Flowers et al. 2018 & Field & Chesapeake Bay (MD) \\
\hline Flowers et al. $2016 \mathrm{~b}$ & Field & Chesapeake Bay (MD) and east coast USA \\
\hline Zhao et al. 2020 & Field & Western Atlantic (Massachusetts to Uruguay) \\
\hline Short et al. 1987 & Field & Atlantic and Pacific coasts USA \\
\hline Muehlstein et al. 1988 & Experiments & North American coasts, including MD and VA \\
\hline Muehlstein et al. 1991 & Field & North American coasts \\
\hline \multicolumn{3}{|l|}{ Growth } \\
\hline Latour et al. 2012 & Field & Chesapeake Bay (MD and VA) \\
\hline Matsche et al. 2010 & Experiments & Chesapeake Bay (MD) \\
\hline Zimmerman and Welsh 2012 & Field & Shenandoah River, WV (upstream of Chesapeake Bay) \\
\hline \multicolumn{3}{|l|}{ Reproduction } \\
\hline Gervasi et al. 2019 & Field & Chesapeake Bay (MD and VA) \\
\hline Barber et al. 1988 & Field & Delaware Bay \\
\hline Palstra et al. 2007 & Experiments & Hungary \\
\hline Kane et al. 2007 & Field & Chesapeake Bay (MD) \\
\hline Stine et al. 2005 & Field & Chesapeake Bay (MD) \\
\hline Small et al. 2019 & Field & Chesapeake Bay and coastal bays (VA) \\
\hline Messick 1994 & Field & Coastal Bays (MD and VA) \\
\hline
\end{tabular}


Table 2 (continued)

\begin{tabular}{|c|c|c|}
\hline Citation & Study type & Study location \\
\hline \multicolumn{3}{|l|}{ Interactions } \\
\hline Fenske et al. 2010 & Field & Chesapeake Bay (MD) \\
\hline Mann et al. 2009 & Field & Chesapeake Bay (VA) \\
\hline Gervasi 2015 & Model simulation & Chesapeake Bay (MD and VA) \\
\hline \multicolumn{3}{|l|}{ Climate change } \\
\hline Lapointe et al. 2014 & Experiments & Chesapeake Bay (VA) \\
\hline Glaspie et al. 2018 & Field & Chesapeake Bay (MD and VA) \\
\hline Hofmann et al. 2001 & Model simulation & Chesapeake Bay (MD and VA) \\
\hline Audemard et al. 2006 & Field & Chesapeake Bay (VA) \\
\hline Soniat et al. 2009 & Field & Delaware Bay and Gulf of Mexico \\
\hline Gieseker 2001 & Field & Chesapeake Bay (MD) \\
\hline Christensen et al. 1974 & Field and experiments & Chesapeake Bay (MD) \\
\hline Perrigault et al. 2011 & Experiments & East coast USA \\
\hline Kaldy 2014 & Experiments & Pacific Northwest USA \\
\hline Brakel et al. 2019 & Experiments & Baltic Sea \\
\hline La Peyre et al. 2006 & Experiments & Louisiana \\
\hline Arnold et al. 2012 & Field & Italy and Chesapeake Bay (MD) \\
\hline Groner et al. 2018a & Experiments & Washington \\
\hline \multicolumn{3}{|l|}{ Aquaculture } \\
\hline Ben-Horin et al. 2018 & Model simulation & \\
\hline Spitznagel 2019 & Field & Chesapeake Bay (MD and VA) and Louisiana \\
\hline Messick and Kennedy 1990 & Experiment & Chesapeake Bay (MD) \\
\hline Sizemore et al. 1975 & Field & Chesapeake Bay \\
\hline Whyte et al. 1994 & Field & Canada \\
\hline Ragone Calvo et al. 1998 & Field & Chesapeake Bay and coastal bays (VA) \\
\hline Ford et al. 2002 & Field & New Jersey \\
\hline Ragone Calvo et al. 2007 & Field & Chesapeake Bay (VA) and New Jersey \\
\hline \multicolumn{3}{|l|}{ Ecosystem effects } \\
\hline Rothschild et al. 1994 & Stock assessment model & Chesapeake Bay (MD) \\
\hline Wilberg et al. 2011 & Stock assessment model & Chesapeake Bay (MD) \\
\hline Reed and Hovel 2006 & Field & California \\
\hline Lefcheck et al. 2017 & Field & Chesapeake Bay \\
\hline Kellogg et al. 2013 & Field & Chesapeake Bay (MD) \\
\hline Newell and Koch 2004 & Model simulation & Chesapeake Bay \\
\hline
\end{tabular}

mycobacteriosis causes an approximate doubling of the natural mortality rate (Hoenig et al. 2017).

Atlantic menhaden (Brevoortia tyrannus) exhibit ulcerative skin lesions from multiple sources that may be connected with fish kills (Webb et al. 2005). The oomycete, Aphanomyces invadans, is thought to cause deep lesions and result in large-scale fish kills around the world. Atlantic menhaden from the Chesapeake Bay have been found with lesions similar to those caused by $A$. invadans, and preliminary testing found that the pathogen cultured from the lesions was an
Aphanomyces spp. similar to A. invadans (Blazer et al. 1999). Atlantic menhaden showed increased mortality with increased injection dose of $A$. invadans, and fish treated with a realistic aqueous exposure developed $14 \%$ lesion prevalence and $11 \%$ mortality (Kiryu et al. 2003). Large mortality events for Atlantic menhaden have also been connected to other diseases. Atlantic menhaden with pre-ulcerative lesions tested positive for Kudoa sp. infections (a myxozoan parasite), while only fish with fully ulcerative lesions tested positive for other bacterial, fungal, and amphizoic amoebae. This suggests that 
the causative agent for the lesions, and potentially the fish mortality events, was Kudoa sp. infection while the others were opportunistic secondary infections that took hold after the ulcer had formed (Webb et al. 2005).

Eastern oyster (Crassostrea virginica) populations in the Chesapeake Bay have been reduced by a combination of factors, including overfishing and infectious diseases (Rothschild et al. 1994). The most notable diseases are caused by the protozoan parasites Haplosporidium costale (SSO), Haplosporidium nelsoni (MSX), and Perkinsus marinus (Dermo). SSO disease has affected eastern oysters in high salinity areas of the Chesapeake Bay since 1959 (Andrews et al. 1962) causing mortality rates of $20-50 \%$ year $^{-1}$ in the 1970s (Andrews and Castagna 1978) and is commonly found in association with MSX disease in the summer months (Andrews 1979). However, because SSO infections require high salinities (>30), they do not affect eastern oysters as severely as do MSX and Dermo disease. The combination of Dermo and MSX disease on eastern oysters in the Bay has caused high mortality since at least the 1960s (Andrews 1979; Ragone Calvo et al. 2003b; Southworth et al. 2010).

MSX disease was introduced into Delaware Bay in the 1950s before making its way to the Chesapeake Bay in 1959 (Andrews 1964). There have been four major epizootics of MSX disease since 1990 in association with increased salinities, three of which (1991-1992, 1995, 1999-2000) were associated with increases in mortality (Tarnowski 2019). All epizootics were arrested by increased freshwater inputs in following years, indicating that decreases in prevalence or severity is likely temporary and that a background reservoir of infection agents persist (Carnegie et al. 2004; Tarnowski 2005). In recent years, MSX-related eastern oyster mortality has declined, even when MSX prevalence is high (Tarnowski 2019), suggesting that population-level resistance may be developing in the Chesapeake Bay, as it did in Delaware Bay (Ford and Bushek 2012).

Dermo disease has likely led to oyster mortalities since the 1940s (Andrews 1979), causing mortality rates of up to $90 \%$ for adults (McCollough et al. 2007; Schulte 2017); Dermo remains prevalent throughout the Bay (Reece et al. 2008). In 2018, Maryland waters of the Chesapeake Bay had $40 \%$ mean infection prevalence, dropping from $69 \%$ in 2017, and below the 29-year average of 67\% (Tarnowski 2019). However, similar to MSX, Dermo disease varies in prevalence spatially and over time throughout the Chesapeake Bay (Ragone Calvo and Burreson 2000; Maryland Department of Natural Resources 2001; Carnegie et al. 2004; Tarnowski 2005). Although low salinitymay mitigate the negative effects of Dermo disease, it does not eradicate the pathogen (Paynter and Burreson 1991), indicating that future periods of high salinity may lead to further epizootics. Over the decades, there is evidence that natural populations of oysters become more tolerant of MSX and Dermo, presumably through natural selection (Bushek and Ford 2016).
Two parasites closely related to $P$. marinus ( $P$. andrewsi and $P$. chesapeaki) and disseminated neoplasia (also referred to as sarcoma) cause infections and are associated with high mortality rates in soft clams (Mya arenaria and Macoma balthica) and razor clam (Tagelus plebeius) populations in Chesapeake Bay (Dungan et al. 2002; Reece et al. 2008). Almost $90 \%$ of M. arenaria clams infected with Perskinsus sp. were also infected with disseminated neoplasia, a transmissible leukemia-like disease of bivalves (Dungan et al. 2002). However, T. plebeius with Perskinsus sp. infections did not have evidence of lesions from disseminated neoplasia (Dungan et al. 2002). Mortality of clams infected with disseminated neoplasia can be as high as 100\% (Farley et al. 1986). Farley et al. (1986) also documented less than $0.1 \%$ prevalence of disseminated neoplasia in M. arenaria between 1969 and 1983 , followed by $53 \%$ prevalence in 1984 . Subsequent studies show that disseminated neoplasia persists in the Bay, with peak prevalence between 33 and 57\% (Farley et al. 1991; Dungan et al. 2002).

Several pathogens may cause mortality in blue crabs (Callinectes sapidus) within the Chesapeake Bay. Paramoeba perniciosa is a parasitic amoeba that affects blue crabs in Chesapeake Bay and the Southeastern US Atlantic coast. P. perniciosa is thought to be limited to high salinity areas (Sprague 1970), although the low salinity threshold has not been defined (Morado 2011). Prevalence of P. perniciosa in Chesapeake Bay is unknown, but infections were detected in nearly $60 \%$ of blue crabs in nearby Chincoteague Bay (Johnson 1977). Heavily infected blue crabs (containing 95 P. perniciosa amoeba/100 hemocytes) experienced $100 \%$ mortality (Newman and Ward 1973), and P. perniciosa infection may lead to significant winter mortality among the blue crab population (Morado 2011). Hematodinium perezi is a parasitic dinoflagellate that causes blue crab mortality in the lower Chesapeake Bay. Mortality of infected blue crabs ranges from 86 to $100 \%$ (Messick and Shields 2000; Shields and Squyars 2000). Infection is linked to salinity, with no infected blue crabs found in low salinity waters (salinity < 11), limited infections in salinities of $11-18$, and highest prevalence $(38 \%)$ found in salinities of 26-30 (Messick and Shields 2000). There are recent reports on $H$. perezi alternate hosts, infections in early juveniles, and effects of climate change (Lohan et al. 2012; Huchin-Mian et al. 2018; Shields 2019).

Several viruses have been described in blue crabs in Maryland, including reo-like, picorna-like, rhabdo-like, and baculoviruses (Johnson 1983). The most well studied is the reo-like virus since re-named $C$. sapidus reovirus 1 (CsRV1). It is associated with mortality of blue crabs in soft-shell production (Bowers et al. 2010), and prevalence may be increased in wild crabs in close proximity to soft crab shedding facilities and in larger animals (Flowers et al. 2018). Originally described in 1977 (Johnson 
1977), CsRV1 was cryptic in wild crabs until molecular tools became available for its detection (Flowers et al. 2016a). The average prevalence of CsRV1 was found to be $20 \%$ in the Chesapeake Bay (Flowers et al. 2016b). However, large spatial and temporal heterogeneity in prevalence $(0$ to $60 \%)$ indicates that poorly understood and complex environmental and life history factors must determine which blue crabs become infected with CsRV1 (Flowers et al. 2018; Zhao et al. 2020).

Eelgrass (Zostera marina) is subject to mortality due to infection by a protist, Labyrinthula zosterae, that causes eelgrass wasting disease. L. zosterae was determined to be the causal agent responsible for coast-wide mortality of eelgrass in the 1930s which accounted for a $90 \%$ reduction in eelgrass biomass (Muehlstein et al. 1988; Muehlstein et al. 1991). While die-offs have continued, most have been localized and not on the scale of the 1930s outbreak (Short et al. 1987). L. zosterae infection is spread between individual plants by direct contact, with potential regional spreading occurring through drifting of infected plants, though little is known of L. zosterae life history post-infection (Muehlstein 1989).

\section{Growth}

Diseases can affect growth, but less is known about the effects of disease on growth than on mortality. In the Chesapeake Bay, few studies have directly evaluated the effects of disease on host growth, but those that do indicate reduced growth in diseased marine organisms. A study of striped bass collected from the Chesapeake Bay found that striped bass with mycobacteriosis had significantly slower growth than disease-negative fish (Latour et al. 2012). Furthermore, Atlantic sturgeon (Acipenser oxyrinchus) with skin and gill infections of the trematode, Nitzschia sturionis, lost weight compared to uninfected Atlantic sturgeon (Matsche et al. 2010). Similarly, American eel (Anguilla rostrata) infected with the swim bladder nematode, Anguillicoloides crassus, had a lower length-at-age than uninfected eels (Zimmerman and Welsh 2012). Dermo disease in the eastern oyster can slow growth and cause a reduction in condition index of the oysters (Paynter and Burreson 1991). Multiple mechanisms, including changes in behavior or physiological responses, could explain the reduced growth of infected individuals. To further complicate matters, the reduction in growth may be difficult to distinguish from size selective mortality (large individuals have a higher mortality rate than smaller individuals).

\section{Reproduction and early life stages}

Diseases can negatively affect reproduction and recruitment by causing changes in maturation, fecundity, spawning behavior, and juvenile survival. At the population level, disease may reduce the effectiveness of spawning individuals or may lower recruitment if infections disproportionately affect the earliest life stages. Lower individual fecundity could reduce the productivity of populations in the Chesapeake Bay. Disease effects on reproductive processes have not been comprehensively studied for marine organisms in the Chesapeake Bay. However, the negative effects of disease, including the combination of decreased growth and increased mortality, can reduce reproductive success indirectly.

Maturation and fecundity can be negatively affected by disease. Striped bass with mycobacteriosis mature earlier and at smaller sizes than healthy fish $(2.65$ years and $322 \mathrm{~mm}$ for diseased, 2.94 years and $343 \mathrm{~mm}$ for healthy; Gervasi et al. 2019). No other reproductive metrics (oocyte development, oocyte size, fecundity, gonadosomatic index, or oocyte dry weight) were affected in diseased fish (Gervasi et al. 2019). In C. virginica, systemic infection by MSX disease decreased oyster fecundity by $81 \%$ (Barber et al. 1988). Decreased fecundity was a result of reduced food intake caused by infection and consequent use of metabolic reserves that would otherwise have been used for gamete production (Barber et al. 1988).

The ability to undertake spawning migrations may be affected by disease. A. crassus causes swim bladder pathology in American eels, including inflammation, lesions, hemorrhaging, and fibrosis (Lefebvre et al. 2011). This swim bladder degradation is thought to reduce swimming efficiency and migratory ability of infected individuals, and migrating silver stage eels with swim bladder impairment may be unable to reach their spawning grounds in the Sargasso Sea (Haro et al. 2000; Palstra et al. 2007).

Recruitment could be negatively affected by disease if it causes increased mortality in juveniles. Atlantic menhaden in the Chesapeake Bay experience mycobacteriosis, but it is unknown if the disease is fatal. Young-of-the-year Atlantic menhaden from Maryland tributaries in the Bay had 2-100\% prevalence of mycobacteriosis, thought to be dependent on the water quality in the tributary (Stine et al. 2005; Kane et al. 2007). H. perezi may affect blue crab recruitment by increasing mortality of the early life stages. Fifty to $100 \%$ of early benthic juveniles were infected with $H$. perezi (Small et al. 2019). Higher prevalence in small crabs than in large crabs may indicate mortality of infected small crabs (i.e., the infected crabs may die at a higher rate than the non-infected crabs resulting in a lower prevalence at later ages; Messick 1994).

\section{Interactions among mortality, growth, and reproduction}

The effects of diseases are sometimes not easily separated into mortality, growth, and reproduction because diseases can affect multiple interacting population dynamics processes. 
Decreased growth can lead to decreased reproductive potential because fecundity is positively related to size for most marine organisms (Hixon et al. 2014). Similarly, diseaseinduced mortality can cause a reduction in the number of large individuals in a population. Because larger individuals are typically the most fecund in the population, increases in mortality or decreases in growth may cause declines in population-level fecundity and decreased reproduction.

Slower growth caused by disease would be expected to also reduce fecundity. American eels that were previously infected with A. crassus had lower length-at-age than uninfected American eels in upper watersheds of the Chesapeake Bay (Zimmerman and Welsh 2012), although a similar pattern was not seen in the lower Potomac River (Fenske et al. 2010). However, the upper watershed may be an important juvenile habitat for female American eels (Goodwin and Angermeier 2003). Therefore, an effect of A. crassus on growth could result in lower reproductive potential because American eels are semelparous with only one opportunity to spawn and smaller American eels would likely have lower fecundity (Zimmerman and Welsh 2012; Jessop 2018). During 2004-2008, $10 \%$ of Atlantic sturgeon from the Chesapeake Bay had infections of $N$. sturionis, which caused reduced growth (Matsche et al. 2010). Smaller size caused by the trematode infection may reduce reproductive success of Atlantic sturgeon in the Chesapeake Bay due to the lack of sufficient nutrition for gonadal development.

Increased mortality due to disease is expected to reduce the abundance of older and large individuals in a population because an increase in mortality at any age causes a truncation of a population's age structure (Quinn and Deriso 1999). For example, diseases have shortened the eastern oyster life expectancy and lifetime fecundity in the James and Wicomico Rivers, where oyster life expectancy is around 3 years compared to an estimated 10-20 years for a population without disease (Mann et al. 2009; Southworth et al. 2010). This is also demonstrated in $M$. arenaria, where sarcomas mostly occur in adult clams. When a severe outbreak occurs in larger clams, infection and subsequent mortalities of infected adult clams lowers the number of individuals available to reproduce. In years of severe infections, both adults and juveniles will be negatively affected, possibly reducing the reproducing population for many years (Farley et al. 1991).

Slower growth and increased mortality due to disease combine to affect lifetime reproductive success. Mycobacteriosis in striped bass has the potential for large reproductive effects through cumulative mortality and reduced growth. Compromised growth due to mycobacteriosis was estimated to cause a $3.3 \%$ decrease in individual lifetime reproductive potential for female striped bass (Gervasi 2015). At the population level, disease-associated increases in natural mortality were estimated to cause a $74.5 \%$ decrease in reproductive output. The combined effects caused a $75.1 \%$ decrease, indicating that mycobacteriosis likely reduces the lifetime reproductive potential of striped bass in the Chesapeake Bay by a substantial amount (Gervasi 2015).

\section{Climate Change}

As indicated by references to climate effects elsewhere in this review, many hosts and pathogens are responsive to climatedriven changes in salinity, temperature, and $\mathrm{pH}$ (Burge et al. 2014). Shifting environmental conditions may affect interactions between hosts and pathogens, which can tilt the balance toward or away from high disease states (Burge et al. 2014; Barbieri et al. 2018). Our understanding of how climate change will affect marine infectious diseases in the Chesapeake Bay is restricted to hosts for which there are long-term infectious disease datasets (Harvell et al. 2002), in particular oysters and striped bass (Hofmann et al. 2001; Bushek and Ford 2016; Groner et al. 2018b). Predicting responses to climate change is further complicated by the synergistic effects of populations responding to multiple climate variables and subsequent changes in the marine community (Harvell et al. 2002; Ward and Lafferty 2004). Although the potential effects of climate change are well documented, the response of organisms to these effects are understudied for many ecosystems and taxonomic groups (Poloczanska et al. 2016), including those in the Chesapeake Bay. Many studies of potential effects of climate change use data from other regions to forecast effects for a new region. We adopted a similar approach in relying on studies from a variety of locations to inform potential responses of Chesapeake Bay species to climate change.

\section{Temperature}

Warming temperatures are expected to cause complex changes in infectious disease dynamics (O'Connor and Bernhardt 2018; Rohr and Cohen 2020). The Chesapeake Bay surface water temperatures are likely to increase $2-5.5^{\circ} \mathrm{C}$ by 2100 (Muhling et al. 2018). As the overall average temperature increases, so will the frequency and duration of marine heat waves, with temperatures regularly reaching numbers currently considered extreme events (Oliver et al. 2018). Warming can affect host-pathogen interactions by changing pathogen development and survival, disease transmission, and host susceptibility (Harvell et al. 2002). The effects of increased temperature on diseases in the Chesapeake Bay have already been observed in some cases. For example, average summer sea 
surface temperatures are correlated with increased mortality for striped bass with mycobacteriosis (Groner et al. 2018b). The combination of hypoxic conditions, increased water temperature, and severe mycobacteriosis reduced the metabolic performance of striped bass more than any individual factor (Lapointe et al. 2014).

In some cases, increased temperature may positively influence the pathogen, negatively affecting the host. Populations of soft clams (M. arenaria) in the Chesapeake Bay are likely to decrease as both sarcomas and Perkinsus sp. have higher virulence with increased temperatures (Farley et al. 1986; Glaspie et al. 2018). In addition, the mean infection intensity of Perkinsus sp. in M. arenaria and T. plebeius increases as temperature and salinity increase and dissolved oxygen decreases (Glaspie et al. 2018). Similarly, the two pathogens that cause the most prevalent diseases affecting eastern oysters in the Chesapeake Bay, Dermo and MSX, proliferate at temperatures above $20^{\circ} \mathrm{C}$ and are inhibited by cold winter temperatures (Hofmann et al. 2001; Audemard et al. 2006; Soniat et al. 2009). Unusually high winter temperatures may facilitate a high survival of over-wintering Dermo and MSX organisms, leading to increased infections in the spring and summer. An increase in infections was observed in 1999 when abnormally high winter and summer temperatures coupled with drought conditions led to increases in Dermo and MSX disease and consequent high mortality of oysters throughout the Bay (Ragone Calvo and Burreson 2000; Gieseker 2001). Similarly, in 2001-2002, 2005-2006, and 2007-2008 the Wicomico River had high winter temperatures (above $5{ }^{\circ} \mathrm{C}$ ), followed by increased oyster mortality and Dermo severity (Southworth et al. 2010).

Alternatively, some host species may experience beneficial effects with increasing temperature. In some clam species (M. balthica and Mercenaria mercenaria) in Chesapeake Bay, the extended periods of warmer weather and water temperatures may decrease effects of disease (Christensen et al. 1974; Perrigault et al. 2011). For example, prevalence of quahog parasite unknown (QPX), a protistan parasite that infects both wild and aquaculture hard clams, in M. mercenaria clams was higher at colder temperatures, and clams in warmer temperatures had a higher rate of healing when exposed to QPX (Perrigault et al. 2011).

Climate change effects can be complicated, as temperature increases may have contrasting effects on disease dynamics depending on the overall rise in temperature. Eelgrass has growth rates that increase linearly with temperatures from 5 to $25^{\circ} \mathrm{C}$, but temperatures over $25^{\circ} \mathrm{C}$ cause decreased photosynthesis and growth in eelgrass, likely leading to enhanced physiological stress and susceptibility to pathogens (Kaldy 2014; Sullivan et al. 2018). The relationship is further complicated as the effect of temperature on the host may be different than the effect on the pathogen. For example, Z. marina collected in the Pacific Northwest naturally infected with
L. zosterae had increased wasting disease severity at $25^{\circ} \mathrm{C}$ compared to plants kept at $10{ }^{\circ} \mathrm{C}$ (Kaldy 2014).

\section{Salinity}

The predicted future salinity of the Chesapeake Bay is complex and spatially dependent, with climate models projecting a freshening of water in the upper Bay but an increase in salinity in the lower Bay (Muhling et al. 2018). Changes in salinity will likely affect organisms' susceptibility to pathogens and the virulence of pathogens. Most hosts and pathogens have a specific salinity niche where they are able to survive, and changes in salinity in the Chesapeake Bay could lead to new host/pathogen interactions or reduced exposure. For example, L. zosterae does not grow in salinities lower than 10 , meaning outbreaks of wasting disease may retreat towards the lower Chesapeake Bay with climate change (Muehlstein et al. 1988). In addition, soft-shell clams infected with transmissible sarcoma have the highest prevalence in the Bay mainstem, and are not detected in areas of freshwater influence (Farley et al. 1991).

The pathogens that cause the most common oyster diseases (MSX, Dermo, and SSO) are strongly influenced by salinity. Specifically, $P$. marinus has high viability in moderate to high salinities of 15-35 (La Peyre et al. 2006), H. nelsonii prefers salinities of 15-25, and H. costale prefers high salinities (>30; Andrews 1979). These salinity constraints result in shifts in infection prevalence and intensity associated with rainfall or other sources of freshwater input, and high winter salinities may lead to increased epizootics in the following spring (Southworth et al. 2010). Droughts resulting in raised salinity caused substantial increases in Dermo and MSX disease in the Chesapeake Bay in 1991-9292, 1995, and 1999-2000, along with a movement of MSX disease into the upper Bay (Gieseker 2001; Mann et al. 2009). High freshwater inputs into the Bay halted further disease expansion and decreased disease severity (Mann et al. 2009; Tarnowski 2019).

\section{Ocean Acidification}

By 2100, the atmosphere in the Chesapeake region will see increases in $\mathrm{CO}_{2}$ concentration of $50-160 \%$ (Najjar et al. 2010). As excess $\mathrm{CO}_{2}$ is absorbed into the Chesapeake Bay, it will change the $\mathrm{pH}$ and alkalinity of the waters resulting in acidification. Chesapeake Bay $\mathrm{pH}$ changes are likely to be spatially dependent; model simulations of the Chesapeake Bay found that $\mathrm{pH}$ increased in the upper Bay, decreased in the lower Bay, and was variable in the mid-Bay from 1986 to 2015 (Shen et al. 2020). These changes to water chemistry are expected to affect the physiology of many important Chesapeake Bay marine organisms. However, there is a general lack of information on the effects of acidification on disease susceptibility of estuarine organisms. One exception is research indicating that future acidification may increase the 
susceptibility of seagrasses to wasting disease outbreaks. High carbon dioxide concentrations result in a $\sim 95 \%$ loss of antimicrobial phenolic acids released by seagrass species (Arnold et al. 2012, 2017). The loss of phenolic acids may be problematic as they inhibit growth of the pathogen responsible for seagrass wasting disease. Alternatively, laboratory studies found that eelgrass experienced less severe wasting disease with higher $\mathrm{CO}_{2}$, although the mechanism for this response is unknown (Groner et al. 2018a). The uncertainty of wasting disease outbreaks with ocean acidification and the expected decrease with warming temperatures and lower salinity further emphasizes the complexity of host-pathogen interactions with climate change and the need for multi-factor experiments.

\section{Aquaculture}

Aquaculture of marine species has increased globally due to declining wild populations combined with the increasing demand for seafood products (FAO 2018). When dense monospecies aggregations are created, aquaculture can exacerbate the spread of disease. Within the Chesapeake Bay, an aquaculture industry currently exists for eastern oyster, hard clam, and soft-shell blue crabs. The transportation of oysters and the introduction of new species for aquaculture have facilitated the spread of infectious diseases globally (Minchin 2007). H. nelsoni (MSX) was introduced to California with the transportation of a foreign species, Crassostrea gigas, from Japan in the early 1900s. Similarly, MSX was likely introduced to Chesapeake Bay in the 1960 s via C. gigas introductions to Delaware Bay in the 1950s (Andrews 1964; Ragone Calvo and Burreson 2000). Although aquaculture has enabled the spread of disease, there are recent suggestions that it may have the potential to reduce disease by filtering pathogens. However, this capability depends on the pathogen, timing of harvest, and the aquaculture species (Burge et al. 2016). As suspension feeders, oysters remove particulates from the water column including parasites, bacteria, and viruses. For non-human pathogenic diseases such as Dermo disease, modeling work suggests that aquaculture oysters may reduce the abundance of pathogens in the water column. If aquaculture populations filter these pathogens from the water column and if they are harvested prior to onset of disease, they may reduce the effect of a pathogen (Ben-Horin et al. 2018). Increasingly, eastern oyster aquaculture in the Chesapeake Bay is conducted with disease resistant oyster strains from selective breeding (Ragone Calvo et al. 2003a; Frank-Lawale et al. 2014).

Within the Chesapeake Bay, blue crabs can be sold as value-added "soft crabs," a colloquial term for the post molt stage of a crab. Many commercial crabbers set aside crabs which look to be nearing a molt (known as peelers), and place them in shedding facilities, which are shallow flow-through or recirculating aquaculture systems. Multiple diseases have been associated with soft crab shedding facilities. For example, infection by CsRV1 was the primary predictor of mortality within shedding facilities, documented in $75 \%$ of dead crabs (Bowers et al. 2010; Spitznagel 2019). Given the prevalence of CsRV1 in shedding facilities, concerns have been raised about the potential for flow-through systems to reintroduce virus to nearby wild populations, and indeed, higher prevalence of CsRV1 has been observed in wild crabs near such facilities (Flowers et al. 2018). Similar to CsRV1, Vibrio spp. (Vibrio parahaemolyticus, V. vulnificus, V. cholerae) have been identified in both wild and shedding facility blue crabs (Messick and Kennedy 1990). Injury- and capturerelated stress inherent to soft-shell facilities may increase the intensity of infection from Vibrio spp. (Sizemore et al. 1975). It remains to be determined whether the association of disease with soft crab production is a consequence of stress related to molting, captivity, or both.

Hard clam aquaculture has a strong presence in the lower Chesapeake Bay and surpassed the wild clam harvest in 2017 (Hudson 2018). QPX infects both wild and aquaculture hard clams, with higher mortality observed in aquaculture settings (Whyte et al. 1994; Ragone Calvo et al. 1998; Smolowitz 2018). Ford et al. (2002) observed significantly higher QPX presence in clam beds planted at higher densities, but overall disease infection and mortality depended on the seed source; hard clams originating from South Carolina had higher prevalence than seed from New Jersey when grown in New Jersey. The northernmost clam stocks had the highest survival rates and lowest prevalence, suggesting that host genotypes are a determinant of QPX susceptibility in hard clams (Ragone Calvo et al. 2007).

\section{Ecosystem Effects}

Diseases can affect habitat, nutrient cycling, and trophic interactions in the Chesapeake Bay by reducing populations of keystone species or ecosystem engineers. Repercussions from reductions in abundance of ecosystem engineers in other systems are well documented, such as coral reef habitats and kelp forests, with the disappearance of primary habitat engineers leading to community phase shifts (Ward and Lafferty 2004; Burge et al. 2014).

The eastern oyster is an ecosystem engineer that forms complex reef structures and is the main source of hard-bottom habitat in the Chesapeake Bay. In addition to habitat production, eastern oysters filter seawater which improves water quality and is important for nutrient cycling (Fig. 2; Kemp et al. 2005; Grabowski and Peterson 2007). The abundance of eastern oyster has declined substantially due to the combined effects of overfishing, disease, and habitat loss (Rothschild et al. 


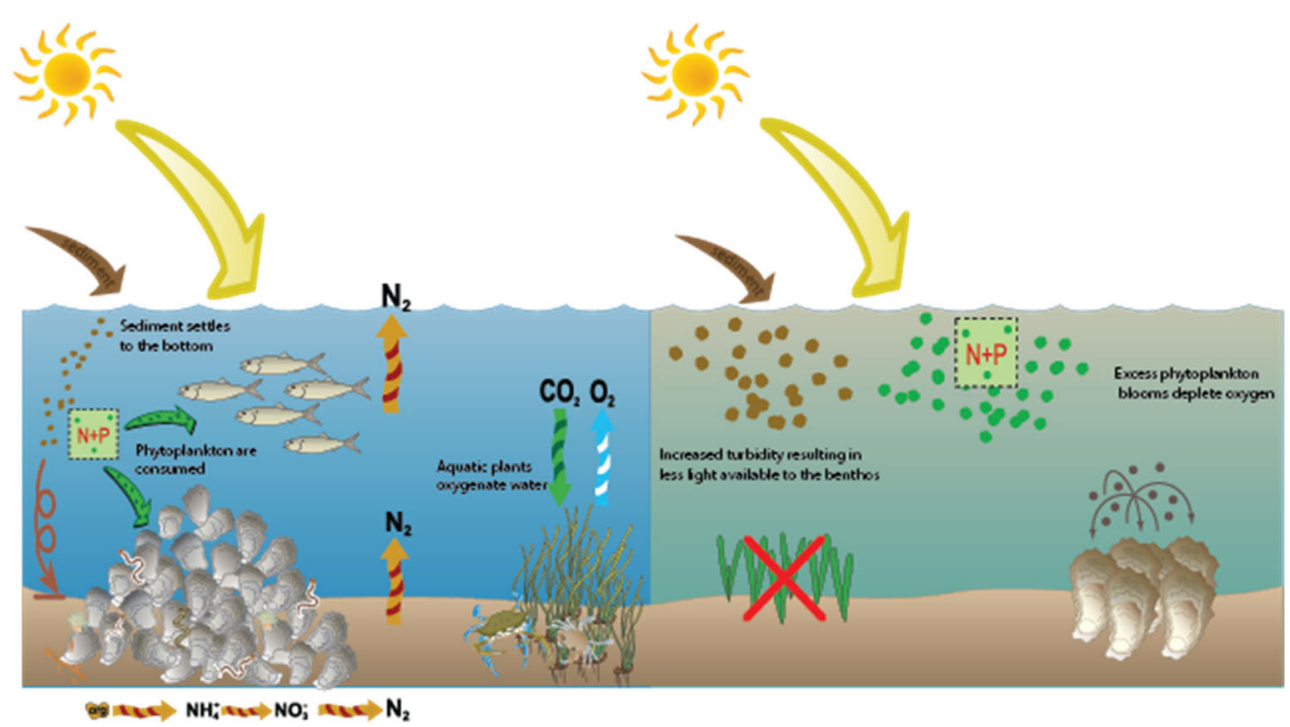

Fig. 2 Comparison of a healthy Chesapeake Bay ecosystem (left) and an example of ecosystem level effects after a disease epizootic affects the oyster population (right). Sediment enters waterways via runoff, bringing with it minerals, such as nitrogen $(\mathrm{N})$ and phosphorous $(\mathrm{P})$. In the healthy ecosystem (left), these nutrients $(\mathrm{N}$ and $\mathrm{P}$ ) promotes growth of phytoplankton, which are in turn consumed by filter feeders and planktivores, such as oysters and menhaden. Some of the $\mathrm{N}$ and $\mathrm{P}$ is assimilated into oyster tissue and shell, and the rest is excreted via biodeposits. These biodeposits can be buried into the underlying substrate, or the $\mathrm{N}$ and $\mathrm{P}$ can be remineralized by benthic bacteria. Through remineralization, nitrification and denitrification, these nutrients can be transformed to nitrogen gas and removed from the aquatic environment. In a healthy ecosystem, oysters and seagrasses help to attenuate wave action, allowing sediment to fall out of the water column and allow sunlight to penetrate the water. Reduced light attenuation creates better habitat for seagrasses, which oxygenate the water and provide habitat for iconic species. As oysters experience disease episodes, these complex systems can become unbalanced, resulting in a less diverse, less productive system. Symbols courtesy of University of Maryland Center for Environmental Science Integration and Application Network
1994; Wilberg et al. 2011). Like eastern oyster, eelgrass provides important nursery and foraging habitat for economically valuable species in Chesapeake Bay, such as blue crabs and numerous commercially exploited finfish (Reed and Hovel 2006). Eelgrass mortality as a result of $L$. zosterae infection causes reduced abundance, resulting in benthic habitat fragmentation and isolated patches which affects numerous marine and some terrestrial species (Muehlstein 1989). Altered eelgrass habitat configurations can lead to reductions in faunal abundance, diversity, and survival (Reed and Hovel 2006). Such loss has been estimated to translate to approximately $236 \mathrm{Mt}$ reduction in epifaunal biomass in the Chesapeake Bay during 1991-2006 (Lefcheck et al. 2017). For commercially exploited species, the valuation of reduced blue crab biomass associated with eelgrass losses would cost the fishery an estimated $\$ 28.6$ to \$76.8 million USD (Lefcheck et al. 2017).

Declines of ecosystem engineer species due to disease effects may also affect nutrient cycling processes. Oysters remove nitrogen from the water column through assimilation into their tissues and shells along with deposition and burial through production of feces and pseudofeces (Kellogg et al. 2013). This supports benthic-pelagic coupling and the production of benthic microalgae (Newell and Mann 2012). The deposition of nutrients in shallow waters decreases their availability in the deeper Bay where organic matter contributes to hypoxia (Kemp et al. 2005). Oysters also consume phytoplankton (Newell et al. 2007) and reduce turbidity (Newell and Koch 2004). A study of local eastern oyster restoration sites in the Chesapeake Bay shows biogeochemical flux rates of $\mathrm{O}_{2}, \mathrm{NH}_{4}{ }^{+}, \mathrm{NO}_{2+3}$, all an order of magnitude greater than unrestored control sites, indicating increased nutrient sequestration and conversion (Kellogg et al. 2013).

\section{Fishery management implications}

The Chesapeake Bay supports important commercial (2017 landings valued at $\$ 73.7 \mathrm{~m}$ for blue crab, $\$ 59.8 \mathrm{~m}$ for eastern oyster, $\$ 23.5 \mathrm{~m}$ for Atlantic menhaden, $\$ 13 \mathrm{~m}$ for striped bass) and recreational fisheries (striped bass support the largest recreational fishery in the USA with 38 million pounds harvested in 2017; National Marine Fisheries Service 2018). Diseases can have substantial effects on fishery sustainability, particularly for the eastern oyster (Wilberg et al. 2011). However, less is known about how fishing practices and regulations may interact with disease and how information on disease effects (mortality, reproduction, movement) may improve management. 
Routine disease monitoring is not conducted for the majority of important fishery species in Chesapeake Bay, and fishery management does not currently use information on disease to modify regulations. Disease prevalence and intensity for oysters are monitored annually within Maryland (e.g., Tarnowski 2019) and periodically in Virginia (e.g., Carnegie et al. 2004), but harvest regulations do not change annually in response to these data. Mycobacteriosis is monitored annually for striped bass in Maryland and periodically in Virginia (Gauthier et al. 2008; Hoenig et al. 2017; Maryland DNR unpublished data). The most recent stock assessment for striped bass began the process of including increased natural mortality due to mycobacteriosis in the Chesapeake Bay in the assessment models, but that model is not currently used for management (Northeast Fisheries Science Center 2019). Monitoring disease-driven mortality is noted as a critical data and analysis need for blue crab (Chesapeake Bay Stock Assessment Committee 2019). Effects of disease on mortality, growth, and reproduction are difficult to estimate, but they can have large effects on population sustainability (Wilberg et al. 2011; Gervasi 2015). Incorporating disease effects in the management of Chesapeake Bay fisheries should be a priority.

\section{Conclusion}

Diseases have had substantial effects on the Chesapeake Bay ecosystem, and they likely have had similar effects in less well-studied estuaries and coastal systems. Despite these effects, there are few estimates of effects of diseases on populations in the Chesapeake Bay, stemming partially from a lack of routine monitoring (Carnegie et al. 2016). This lack of monitoring highlights the need for new monitoring systems. Models to forecast disease dynamics and effects are also rare (Groner et al. 2016). For the organisms with population models, disease is often not explicitly included (Fenske et al. 2011; Miller et al. 2011; Wilberg et al. 2011). While improving understanding of disease effects on marine populations in estuarine and coastal ecosystems is often listed as a high priority, there is still a lack of knowledge about the roles of disease on populations, fisheries, and ecosystems. Advances in the application of molecular methods to track disease agents should make this goal more attainable (e.g., Burge et al. 2016; Zhao et al. 2020). Effects of diseases on coastal ecosystems are expected to increase in the future including increased virulence of diseases, increased host stress, and changes in the ranges of diseases and hosts (Cohen et al. 2018). Because anthropogenic stresses are thought to exacerbate effects of diseases, estuaries and the coastal ocean are likely areas that will show the largest effects (Groner et al. 2016). Additional study of disease prevalence and effects on population dynamics is necessary to accurately incorporate the effects of disease in management for marine organisms in the Chesapeake Bay and other coastal systems.

Acknowledgments We thank the associate editor and two anonymous reviewers for helpful comments that improved this manuscript.

Open Access This article is licensed under a Creative Commons Attribution 4.0 International License, which permits use, sharing, adaptation, distribution and reproduction in any medium or format, as long as you give appropriate credit to the original author(s) and the source, provide a link to the Creative Commons licence, and indicate if changes were made. The images or other third party material in this article are included in the article's Creative Commons licence, unless indicated otherwise in a credit line to the material. If material is not included in the article's Creative Commons licence and your intended use is not permitted by statutory regulation or exceeds the permitted use, you will need to obtain permission directly from the copyright holder. To view a copy of this licence, visit http://creativecommons.org/licenses/by/4.0/.

\section{References}

Andrews, J.D. 1964. Oyster mortality studies in Virginia. IV. MSX in James River public seed beds. Proceedings of the National Shellfisheries Association 53: 65-84.

Andrews, J.D. 1979. Oyster diseases in Chesapeake Bay. Marine Fisheries Review 41 (1-2): 45-53.

Andrews, J.D., and M. Castagna. 1978. Epizootiology of Minchinia costalis in susceptible oysters in Seaside Bays of Virginia's Eastern Shore, 1959-1976. Journal of Invertebrate Pathology 32 (2): 124-138.

Andrews, J.D., J.L. Wood, and H.D. Hoese. 1962. Oyster mortality studies in Virginia III. Epizootiology of a disease caused by Haplosporidium costale. Journal of Invertebrate Pathology 4: 327-343.

Arnold, T., C. Mealey, H. Leahey, A.W. Miller, J.M. Hall-Spencer, M. Milazzo, and K. Maers. 2012. Ocean acidification and the loss of phenolic substances in marine plants. PLoS One 7 (4): e35107.

Arnold, T.M., R.C. Zimmerman, K.A.M. Engelhardt, and J.C. Stevenson. 2017. Twenty-first century climate change and submerged aquatic vegetation in a temperate estuary: the case of Chesapeake Bay. Ecosystem Health and Sustainability 3 (7): 1353283.

Audemard, C., L.M. Ragone Calvo, K.T. Paynter, K.S. Reece, and E.M. Burreson. 2006. Real-time PCR investigation of parasite ecology: in situ determination of oyster parasite Perkinsus marinus transmission dynamics in lower Chesapeake Bay. Parasitology 132 (6): 827-842.

Barber, B.J., S.E. Ford, and H.H. Haskin. 1988. Effects of the parasite MSX (Haplosporidium nelsoni) on oyster (Crassostrea virginica) energy metabolism. I. Condition index and relative fecundity. Journal of Shellfish Research 7 (1): 25-31.

Barbieri, M., C. Duncan, A.L. Harting, K.L. Pabilonia, T.C. Johanos, T. Goldstein, S.J. Robinson, and C.L. Littnan. 2018. Survey for placental disease and reproductive pathogens in the endangered Hawaiian monk seal (Neomonachus schauinslandi). Journal of Wildlife Diseases 54 (3): 564-568.

Ben-Horin, T., C.A. Burge, D. Bushek, M.L. Groner, D.A. Proestou, L.I. Huey, G. Bidegain, and R.B. Carnegie. 2018. Intensive oyster aquaculture can reduce disease impacts on sympatric wild oysters. Aquaculture Environment Interactions 10: 557-567.

Blazer, V.S., W.K. Vogelbein, C.L. Densmore, E.B. May, J.H. Lilley, and D.E. Zwerner. 1999. Aphanomyces as a cause of ulcerative skin 
lesions of menhaden from chesapeake bay tributaries. Journal of Aquatic Animal Health 11 (4): 340-349.

Bowers, H.A., G.A. Messick, A. Hanif, R. Jagus, L. Carrion, O. Zmora, and E.J. Schott. 2010. Physicochemical properties of doublestranded RNA used to discover a reo-like virus from blue crab Callinectes sapidus. Diseases of Aquatic Organisms 93 (1): 17-29.

Brakel, J., S. Jakobsson-Thor, A.C. Bockelmann, and T.B.H. Reusch. 2019. Modulation of the eelgrass - Labyrinthula zosterae interaction under predicted ocean warming, salinity change and light limitation. Frontiers in Marine Science 6: 1-13.

Burge, C.A., C. Mark Eakin, C.S. Friedman, B. Froelich, P.K. Hershberger, E.E. Hofmann, L.E. Petes, K.C. Prager, E. Weil, B.L. Willis, S.E. Ford, and C.D. Harvell. 2014. Climate change influences on marine infectious diseases: implications for management and society. Annual Review of Marine Science 6 (1): 249-277.

Burge, C.A., C.J. Closek, C.S. Friedman, M.L. Groner, C.M. Jenkins, A. Shore-Maggio, and J.E. Welsh. 2016. The use of filter-feeders to manage disease in a changing world. Integrative and Comparative Biology 56 (4): 573-587.

Bushek, D., and S.E. Ford. 2016. Anthropogenic impacts on an oyster metapopulation: pathogen introduction, climate change and responses to natural selection. Elementa: Science of the Anthropocene 4: 000119.

Cardinal, J. L. 2001. Mycobacteriosis in striped bass, Morone saxatilis, from Virginia Waters of Chesapeake Bay. College of William and Mary- Virginia Institute of Marine Science.

Carnegie, R. B., L. M. Ragone Calvo, and E. M. Burreson. 2004. Status of the major oyster diseases in Virginia 2003: a summary of the annual monitoring program. https://doi.org/10.21220/V5Z43K.

Carnegie, R.B., I. Arzul, and D. Bushek. 2016. Managing marine mollusc diseases in the context of regional and international commerce: policy issues and emerging concerns. Philosophical Transactions of the Royal Society, B: Biological Sciences 371 (1689): 20150215.

Chesapeake Bay Stock Assessment Committee. 2019. 2019 Chesapeake Bay blue crab advisory report.

Christensen, D.J., C.A. Farley, and F.G. Kern. 1974. Epizootic neoplasms in the clam Macoma balthica (L.) from Chesapeake Bay. Journal of the National Cancer Institute 52 (6): 1739-1749.

Cohen, R., C. James, A. Lee, M. Martinelli, W. Muraoka, M. Ortega, R. Sadowski, L. Starkey, A. Szesciorka, S. Timko, E. Weiss, and P. Franks. 2018. Marine Host-Pathogen Dynamics: Influences of Global Climate Change. Oceanography 31 (2): 182-193.

Dungan, C.F., R.M. Hamilton, K.L. Hudson, C.B. McCollough, and K.S. Reece. 2002. Two epizootic diseases in Chesapeake Bay commercial clams, Mya arenaria and Tagelus plebeius. Diseases of Aquatic Organisms 50 (1): 67-78.

FAO. 2018. The state of the world fisheries and aquaculture 2018- meeting the sustainable development goals. Rome.

Farley, C.A., S. Otto, and C. Reinisch. 1986. New occurrence of epizootic sarcoma in Chesapeake Bay soft shell clams, Mya arenaria. Fishery Bulletin 84 (4): 851-857.

Farley, C.A., D.L. Plutschak, R.F. Scott, C. Haven, and B. Neck. 1991. Epizootiology and distribution of transmissible sarcoma in Maryland softshell clams, Mya arenaria, 1984-1988. Environmental Health Prespectives 90: 35-41.

Fenske, K.H., D.H. Secor, and M.J. Wilberg. 2010. Demographics and parasitism of American eels in the Chesapeake Bay, USA. Transactions of the American Fisheries Society 139 (6): 1699-1710.

Fenske, K.H., M.J. Wilberg, D.H. Secor, and M.C. Fabrizio. 2011. An age- and sex-structured assessment model for American eels (Anguilla rostrata) in the Potomac River, Maryland. Canadian Journal of Fisheries and Aquatic Sciences 68 (6): 1024-1037.

Flowers, E.M., T.R. Bachvaroff, J.V. Warg, J.D. Neill, M.L. Killian, A.S. Vinagre, S. Brown, A.S. Almeida, and E.J. Schott. 2016a. Genome sequence analysis of CsRV1: a pathogenic reovirus that infects the blue crab Callinectes sapidus across its trans-hemispheric range. Frontiers in Microbiology 7: 126.

Flowers, E.M., K. Simmonds, G.A. Messick, L. Sullivan, and E.J. Schott. 2016b. PCR-based prevalence of a fatal reovirus of the blue crab, Callinectes sapidus (Rathbun) along the northern Atlantic coast of the USA. Journal of Fish Diseases 39 (6): 705-714.

Flowers, E.M., A.F. Johnson, R. Aguilar, and E.J. Schott. 2018. Prevalence of the pathogenic crustacean virus Callinectes sapidus reovirus 1 near flow-through blue crab aquaculture in Chesapeake Bay, USA. Diseases of Aquatic Organisms 129 (2): 135-144.

Ford, S.E., and D. Bushek. 2012. Development of resistance to an introduced marine pathogen by a native host. Journal of Marine Research 70 (2): 205-223.

Ford, S.E., J.N. Kraeuter, R.D. Barber, and G. Mathis. 2002. Aquaculture-associated factors in QPX disease of hard clams: density and seed source. Aquaculture 208 (1-2): 23-38.

Ford, S.E., M. Cummings, and E.N. Powell. 2006. Estimating mortality in natural assemblages of oysters. Estuaries and Coasts 29 (3): 361374.

Frank-Lawale, A., S.K. Allen, and L. Dégremont. 2014. Breeding and domestication of eastern oyster (Crassostrea virginica) lines for culture in the mid-atlantic, USA: line development and mass selection for disease resistance. Journal of Shellfish Research 33 (1): 153-165.

Gauthier, D.T., R.J. Latour, D.M. Heisey, C.F. Bonzek, J. Gartland, E.J. Burge, and W.K. Vogelbein. 2008. Mycobacteriosis-associated mortality in wild striped bass (Morone saxatilis) from Chesapeake Bay, USA. Ecological Applications 18 (7): 1718-1727.

Gervasi, C.L. 2015. The reproductive biology of striped bass (Morone saxatilis) in the Chesapeake Bay. College of William and MaryVIMS.

Gervasi, C.L., S.K. Lowerre-Barbieri, W.K. Vogelbein, J. Gartland, and R.J. Latour. 2019. The reproductive biology of Chesapeake Bay striped bass with consideration of the effects of mycobacteriosis. Bulletin of Marine Science 95 (2): 117-137.

Gieseker, C. 2001. Year 2000 Maryland Oyster Disease Status Report.

Glaspie, C.N., R.D. Seitz, M.B. Ogburn, C.F. Dungan, and A.H. Hines. 2018. Impacts of habitat, predators, recruitment, and disease on softshell clams Mya arenaria and stout razor clams Tagelus plebeius in Chesapeake Bay. Marine Ecology Progress Series 603: 117-133.

Goodwin, K.R., and P.L. Angermeier. 2003. Demographic characteristics of American eel in the Potomac river drainage, Virginia. Transactions of the American Fisheries Society 132 (3): 524-535.

Grabowski, J.H., and C.H. Peterson. 2007. Restoring oyster reefs to recover ecosystem services. Pages 281-298 Ecosystem Engineers. Elesevier.

Groner, M.L., J. Maynard, R. Breyta, R.B. Carnegie, A. Dobson, C.S. Friedman, B. Froelich, M. Garren, F.M.D. Gulland, S.F. Heron, R.T. Noble, C.W. Revie, J.D. Shields, R. Vanderstichel, E. Weil, S. Wyllie-Echeverria, and C.D. Harvell. 2016. Managing marine disease emergencies in an era of rapid change. Philosophical Transactions of the Royal Society, B: Biological Sciences 371 (1689): 20150364.

Groner, M.L., C.A. Burge, R. Cox, N.D. Rivlin, M. Turner, K.L. Van Alstyne, S. Wyllie-Echeverria, J. Bucci, P. Staudigel, and C.S. Friedman. 2018a. Oysters and eelgrass: potential partners in a high pCO2 ocean. Ecology 99 (8): 1802-1814.

Groner, M.L., J.M. Hoenig, R. Pradel, R. Choquet, W.K. Vogelbein, D.T. Gauthier, and M.A.M. Friedrichs. 2018b. Dermal mycobacteriosis and warming sea surface temperatures are associated with elevated mortality of striped bass in Chesapeake Bay. Ecology and Evolution 8 (18): 9384-9397.

Haro, A., W. Richkus, K. Whalen, A. Hoar, W.-D. Busch, S. Lary, T. Brush, and D. Dixon. 2000. Population decline of the American eel: implications for research and management. Fisheries 25 (9): 7-16. 
Harvell, C.D., C.E. Mitchell, J.R. Ward, S. Altizer, A.P. Dobson, R.S. Ostfeld, and M.D. Samuel. 2002. Climate warming and disease risks for terrestrial and marine biota. Science 296 (5576): 2158-2162.

Hixon, M.A., D.W. Johnson, and S.M. Sogard. 2014. BOFFFFs: on the importance of conserving old-growth age structure in fishery populations. ICES Journal of Marine Science 71 (8): 2171-2185.

Hoenig, J.M., M.L. Groner, M.W. Smith, W.K. Vogelbein, D.M. Taylor, D.F. Landers, J.T. Swenarton, D.T. Gauthier, P. Sadler, M.A. Matsche, A.N. Haines, H.J. Small, R. Pradel, R. Choquet, and J.D. Shields. 2017. Impact of disease on the survival of three commercially fished species. Ecological Applications 27 (7): 2116-2127.

Hofmann, E., S. Ford, E. Powell, and J. Klinck. 2001. Modeling studies of the effect of climate variability on MSX disease in eastern oyster (Crassostrea virginica) populations. Hydrobiologia 460 (1): 195212

Huchin-Mian, J.P., H.J. Small, and J.D. Shields. 2018. The influence of temperature and salinity on mortality of recently recruited blue crabs, Callinectes sapidus, naturally infected with Hematodinium perezi (Dinoflagellata). Journal of Invertebrate Pathology 152: 816.

Hudson, K. 2018. Virginia shellfish aquaculture situation and outlook report results of the 2017 Virginia shellfish aquaculture crop reporting survey. Page VIMS Marine Resource Report No. 20189. Virginia Sea Grant VSG-18-3.

Jacobs, J.M., M.R. Rhodes, A. Baya, R. Reimschuessel, H. Townsend, and R.M. Harrell. 2009. Influence of nutritional state on the progression and severity of mycobacteriosis in striped bass Morone saxatilis. Diseases of Aquatic Organisms 87 (3): 183-197.

Jessop, B.M. 2018. American eel fecundity and ovary maturation in relation to body size and geographic distribution. Marine and Coastal Fisheries 10 (2): 169-189.

Johnson, P. T. 1983. Diseases casued by viruses, rickettsia, bacteria and fungi. Pages 2-78 in A. J. Provenzano Jr., editor. The Biology of Crustacea, Vol. 6. Academic Press, New York, NY.

Johnson, P.T. 1977. Paramoebiasis in the blue crab, Callinectes sapidus. Journal of Invertebrate Pathology 29 (3): 308-320.

Kaldy, J.E. 2014. Effect of temperature and nutrient manipulations on eelgrass Zostera marina L. from the Pacific Northwest, USA. Journal of Experimental Marine Biology and Ecology 453: 108115.

Kane, A.S., C.B. Stine, L. Hungerford, M. Matsche, C. Driscoll, and A.M. Baya. 2007. Mycobacteria as environmental portent in Chesapeake Bay fish species. Emerging Infectious Diseases 13 (2): 329-331.

Kellogg, M.L., J.C. Cornwell, M.S. Owens, and K.T. Paynter. 2013. Denitrification and nutrient assimilation on a restored oyster reef. Marine Ecology Progress Series 480: 1-19.

Kemp, W.M., W.R. Boynton, J.E. Adolf, D.F. Boesch, W.C. Boicourt, G. Brush, J.C. Cornwell, T.R. Fisher, P.M. Glibert, J.D. Hagy, L.W. Harding, E.D. Houde, D.G. Kimmel, W.D. Miller, R.I.E. Newell, M.R. Roman, E.M. Smith, and J.C. Stevenson. 2005. Eutrophication of Chesapeake Bay: historical trends and ecological interactions. Marine Ecology Progress Series 303: 1-29.

Keppel, A.G., D.L. Breitburg, G.H. Wikfors, R.B. Burrell, and V.M. Clark. 2015. Effects of co-varying diel-cycling hypoxia and $\mathrm{pH}$ on disease susceptibility in the eastern oyster Crassostrea virginica. Marine Ecology Progress Series 538: 169-183.

Kirk, R.S. 2003. The impact of Anguillicola crassus on European eels. Fisheries Management and Ecology 10 (6): 385-394.

Kiryu, Y., J.D. Shields, W.K. Vogelbein, H. Kator, and V.S. Blazer. 2003. Infectivity and pathogenicity of the oomycete Aphanomyces invadans in Atlantic menhaden Brevoortia tyrannus. Diseases of Aquatic Organisms 54 (2): 135-146.

La Peyre, M., S. Casas, and J. La Peyre. 2006. Salinity effects on viability, metabolic activity and proliferation of three Perkinsus species. Diseases of Aquatic Organisms 71 (1): 59-74.
Lapointe, D., W.K. Vogelbein, M.C. Fabrizio, D.T. Gauthier, and R.W. Brill. 2014. Temperature, hypoxia, and mycobacteriosis: effects on adult striped bass Morone saxatilis metabolic performance. Diseases of Aquatic Organisms 108 (2): 113-127.

Latour, R.J., D.T. Gauthier, J. Gartland, C.F. Bonzek, K.A. Mcnamee, and W.K. Vogelbein. 2012. Impacts of mycobacteriosis on the growth of striped bass (Morone saxatilis) in Chesapeake Bay. Canadian Journal of Fisheries and Aquatic Sciences 69 (2): 247 258.

Lefcheck, J.S., D.J. Wilcox, R.R. Murphy, S.R. Marion, and R.J. Orth. 2017. Multiple stressors threaten the imperiled coastal foundation species eelgrass (Zostera marina) in Chesapeake Bay, USA. Global Change Biology 23 (9): 3474-3483.

Lefebvre, F., G. Fazio, and A.J. Crivelli. 2011. Anguillicoloides crassus. Pages 310-326 Fish Parasites: Pathobiology and Protection.

Lohan, K.M., K.S. Reece, T.L. Miller, K.N. Wheeler, H.J. Small, and J.D. Shields. 2012. The role of alternate hosts in the ecology and life history of Hematodinium sp., a parasitic dinoflagellate of the blue crab (Callinectes sapidus). Journal of Parasitology 98 (1): 73-84.

Mann, R., M. Southworth, J.M. Harding, and J.A. Wesson. 2009. Population studies of the native Eastern oyster, Crassostrea Virginica, (Gmelin, 1791) in the James River, Virginia, USA. Journal of Shellfish Research 28 (2): 193-220.

Maryland Department of Natural Resources. 2001. Maryland oyster population status report 1996-2000 fall surveys.

Matsche, M.A., J.R. Flowers, E.L. Markin, and C.P. Stence. 2010. Observations and treatment of Nitzschia sturionis on Atlantic sturgeon from Chesapeake Bay. Journal of Aquatic Animal Health 22 (3): $174-181$.

McCollough, C.B., B.W. Albright, G.R. Abbe, L.S. Barker, and C.F. Dungan. 2007. Aquisition and progression of Perkinsus marinas infections by specific-pathogen-free juvenile oysters (Crassostrea virginica Gmelin) in a mesohaline Chesapeake Bay tributary. Journal of Shell 26 (2): 465-477.

Messick, G.A. 1994. Hematodinium perezi infections in adult and juvenile blue crabs Callinectes sapidus from coastal bays of Maryland and Virginia, USA. Diseases of Aquatic Organisms 19: 77-82.

Messick, G.A., and V.S. Kennedy. 1990. Putative bacterial and viral infections in blue crabs, Callinectes sapidus Rathburn, 1986 held in flow-through or a re-circulating system. Journal of Shellfish Research 9: 33-40.

Messick, G.A., and J.D. Shields. 2000. Epizootiology of the parasitic dinoflagellate Hematodinium sp. in the American blue crab Callinectes sapidus. Diseases of Aquatic Organisms 43 (2): 139 152.

Miller, T.J., M.J. Wilberg, A.R. Colton, G.R. Davis, A. Sharov, R.N. Lipcius, G.M. Ralph, E.G. Johnson, and A.G. Kaufman. 2011. Stock assesment of blue crab in Chesapeake Bay 2011. Solomons: Page stock assessment report.

Minchin, D. 2007. Aquaculture and transport in a changing environment: overlap and links in the spread of alien biota. Marine Pollution Bulletin 55 (7-9): 302-313.

Morado, J.F. 2011. Protistan diseases of commercially important crabs: a review. Journal of Invertebrate Pathology 106 (1): 27-53.

Muehlstein, L.K. 1989. Perspectives on the wasting disease of eelgrass Zostera marina. Diseases of Aquatic Organisms 7 (3): 211-221.

Muehlstein, L.K., D. Porter, and F.T. Short. 1988. Labyrinthula sp., a marine slime mold producing the symptoms of wasting disease in eelgrass, Zostera marina. Marine Biology 99 (4): 465-472.

Muehlstein, L.K., D. Porter, and F.T. Short. 1991. Labyrinthula zosterae sp. nov., the causative agent of wasting disease of eelgrass, Zostera marina. Mycologia 83 (2): 180-191.

Muhling, B.A., C.F. Gaitán, C.A. Stock, V.S. Saba, D. Tommasi, and K.W. Dixon. 2018. Potential salinity and temperature futures for the Chesapeake Bay using a statistical downscaling spatial disaggregation framework. Estuaries and Coasts 41 (2): 349-372. 
Najjar, R.G., C.R. Pyke, M.B. Adams, D. Breitburg, C. Hershner, W.M. Kemp, R. Howarth, M.R. Mulholland, M. Paolisso, and D. Secor. 2010. Potential climate-change impacts on the Chesapeake Bay. Estuarine, Coastal and Shelf Science 86 (1): 1-20.

National Marine Fisheries Service. 2018. Fisheries economics of the United States, 2016. Page U.S. Dept. of Commerce, NOAA Technical Memorandum.

Newell, R.I.E., and E.W. Koch. 2004. Modeling seagrass density and distribution in response to changes in turbidity stemming from bivalve filtration and seagrass sediment stabilization. Estuaries 27 (5): 793-806.

Newell, R.I.E., and R. Mann. 2012. Shellfish aquaculture: ecosystem effects, benthic-pelagic coupling and potential for nutrient trading. A Report Prepared for the Secretary of Natural Resources, Commonwealth of Virginia. https://www.chesapeakebay.net/ channel files/18087/attachment v - oyster aquaculture report 2 . pdf. Accessed 17 Feb 2021.

Newell, R.I.E., W.M. Kemp, J.D. Hagy, C.F. Cerco, J.M. Testa, and W.R. Boynton. 2007. Top-down control of phytoplankton by oysters in Chesapeake Bay, USA: Comment on Pomeroy et al. (2006). Marine Ecology Progress Series 341: 293-298.

Newman, M.W., and G.E. Ward. 1973. An epizootic of blue crabs, Callinectes sapidus, caused by Paramoeba perniciosa. Journal of Invertebrate Pathology 22 (3): 329-334.

Northeast Fisheries Science Center. 2019. 66st Northeast Regional Stock Assessment Workshop (66th SAW) Assessment Report. US Dept Commer, Northeast Fish Sci Cent Ref Doc. 19-08 (August):1170.

O'Connor, M.I., and J.R. Bernhardt. 2018. The metabolic theory of ecology and the cost of parasitism. PLoS Biology 16 (4): 2-7.

Oliver, E.C.J., M.G. Donat, M.T. Burrows, P.J. Moore, D.A. Smale, L.V. Alexander, J.A. Benthuysen, M. Feng, A. Sen Gupta, A.J. Hobday, N.J. Holbrook, S.E. Perkins-Kirkpatrick, H.A. Scannell, S.C. Straub, and T. Wernberg. 2018. Longer and more frequent marine heatwaves over the past century. Nature Communications 9 (1): 1 12.

Palstra, A.P., D.F.M. Heppener, V. van Ginneken, C. Székely, and G. Thillart. 2007. Swimming performance of silver eels is severely impaired by the swim-bladder parasite Anguillicola crassus. Journal of Experimental Marine Biology and Ecology 352 (1): 244-256.

Paynter, K. T., and E. M. Burreson. 1991. Effects of Perkinsus marinus infection in the eastern oyster, Crassostrea virginica: II. Disease development and impact on growth rate at different salinities. Journal of Shellfish Research 10 (2): 425-431.

Perrigault, M., S.F. Dahl, E.P. Espinosa, L. Gambino, and B. Allam. 2011. Effects of temperature on hard clam (Mercenaria mercenaria) immunity and QPX (Quahog Parasite Unknown) disease development: II. Defense parameters. Journal of Invertebrate Pathology 106 (2): 322-332.

Poloczanska, E.S., M.T. Burrows, C.J. Brown, J. García Molinos, B.S. Halpern, O. Hoegh-Guldberg, C.V. Kappel, P.J. Moore, A.J. Richardson, and D.S. Schoeman. 2016. Responses of marine organisms to climate change across oceans. Frontiers in Marine Science 3: 62.

Quinn, T.J., and R.B. Deriso. 1999. Quantitative Fish Dynamics. New York: Oxford University Press.

Ragone Calvo, L.M., and E.M. Burreson. 2000. Status of the major oyster diseases in Virginia 1999. A summary of the annual monitoring program.

Ragone Calvo, L.M., J.G. Walker, and E.M. Burreson. 1998. Prevalence and distribution of QPX, Quahog Parasite Unknown, in hard clams Mercenaria mercenaria in Virginia, USA. Diseases of Aquatic Organisms 33 (3): 209-219.

Ragone Calvo, L.M., G.W. Calvo, and E.M. Burreson. 2003a. Dual disease resistance in a selectively bred eastern oyster, Crassostrea virginica, strain tested in Chesapeake Bay. Aquaculture 220 (1-4): 69-87.
Ragone Calvo, L.M., C.F. Dungan, B.S. Roberson, and E.M. Burreson. 2003b. Systematic evaluation of factors controlling Perkinsus marinus transmission dynamics in lower Chesapeake Bay. Diseases of Aquatic Organisms 56 (1): 75-86.

Ragone Calvo, L.M., S.E. Ford, J.N. Kraeuter, D.F. Leavitt, R. Smolowitz, and E.M. Burreson. 2007. Influence of host genetic origin and geographic location on QPX disease in Northern Quahogs (=hard clams), Mercenaria mercenaria. Journal of Shellfish Research 26 (1): 109-119.

Reece, K.S., C.F. Dungan, and E.M. Burreson. 2008. Molecular epizootiology of Perkinsus marinus and P. chesapeaki infections among wild oysters and clams in Chesapeake Bay, USA. Diseases of Aquatic Organisms 82 (3): 237-248.

Reed, B.J., and K.A. Hovel. 2006. Segrass habitat disturbance: how loss and fragmentation of eelgrass Zostera marina influences epifaunal abundance and diversity. Marine Ecology Progress Series 326: $133-143$

Rohr, J.R., and J.M. Cohen. 2020. Understanding how temperature shifts could impact infectious disease. PLoS Biology 18 (11): 1-13.

Rothschild, B.J., J.S. Ault, P. Goulletquer, and M. Héral. 1994. Decline of the Chesapeake Bay oyster population: a century of habitat destruction and overfishing. Marine Ecology Progress Series 111 (1): 29-39.

Schulte, D.M. 2017. History of the Virginia oyster fishery, Chesapeake Bay, USA. Frontiers in Marine Science. https://doi.org/10.3389/ fmars.2017.00127.

Shen, C., J.M. Testa, M. Li, and W.J. Cai. 2020. Understanding anthropogenic impacts on $\mathrm{pH}$ and aragonite saturation state in Chesapeake Bay: insights from a 30-year model study. Journal of Geophysical Research - Biogeosciences 125(7):e2019JG005620.

Shields, J.D. 2019. Climate change enhances disease processes in crustaceans: case studies in lobsters, crabs, and shrimps. Journal of Crustacean Biology 39 (6): 673-683.

Shields, J.D., and C.M. Squyars. 2000. Mortality and hematology of blue crabs, Callinectes sapidus, experimentally infected with the parasitic dinoflagellate Hematodinium perezi. Fishery Bulletin 98 (1): 139-152.

Short, F.T., L.K. Muehlstein, and D. Porter. 1987. Eel grass wasting disease: casue and recurrence of a marine epidemic. The Biological Bulletin 173 (3): 557-562.

Sizemore, R.K., R.R. Colwell, H.S. Tubiash, and T.E. Lovelace. 1975. Bacterial flora of the hemolymph of the blue crab, Callinectes sapidus: numerical taxonomy. Journal of Applied Microbiology 29 (3): 393-399.

Small, H.J., J.P. Huchin-Mian, K.S. Reece, K.M.P. Lohan, M.J. Butler IV, and J.D. Shields. 2019. Parasitic dinoflagellate Hematodinium perezi prevalence in larval and juvenile blue crabs Callinectes sapidus from coastal bays of Virginia. Diseases of Aquatic Organisms 134 (3): 215-222.

Smolowitz, R. 2018. A review of QPX disease in the northern quahog (= hard clam) Mercenaria mercenaria. Journal of Shellfish Research 37 (4): 807-819.

Soniat, T.M., E.E. Hofmann, J.M. Klinck, and E.N. Powell. 2009. Differential modulation of eastern oyster (Crassostrea virginica) disease parasites by the El Nino Southern Oscillation and the North Atlantic Oscillation. International Journal of Earth Sciences 98 (1): 99-114.

Southworth, M., J.M. Harding, J.A. Wesson, and R. Mann. 2010. Oyster (Crassostrea virginica, Gmelin 1791) population dynamics on public reefs in the Great Wicomico River, Virginia, USA. Journal of Shellfish Research 29 (2): 271-290.

Spitznagel, M. 2019. Mortality and revirus infection in soft-shell blue crab (Callinectes sapidus) aquaculture. College Park: University of Maryland.

Sprague, V. 1970. Some protozoan parasites and hyperparasites in marine decapod Crustacea. American Fisheriesi Society. 
Stine, C.B., A.M. Baya, J.D. Salierno, M. Kollner, and A.S. Kane. 2005. Mycobacterial infection in laboratory-maintained Atlantic menhaden. Journal of Aquatic Animal Health 17 (4): 380-385.

Stine, C.B., A.S. Kane, and A.M. Baya. 2010. Mycobacteria isolated from Chesapeake Bay fish. Journal of Fish Diseases 33 (1): 39-46.

Sullivan, B.K., S.M. Trevathan-Tackett, S. Neuhauser, and L.L. Govers. 2018. Review: host-pathogen dynamics of seagrass diseases under future global change. Marine Pollution Bulletin 134: 75-88.

Tarnowski, M. 2005. Maryland oyster population status report 2003 and 2004 fall surveys. Annapolis, MD.

Tarnowski, M. 2019. Maryland oyster population status report 2018 fall survey. Annapolis, MD.

Ward, J.R., and K.D. Lafferty. 2004. The elusive baseline of marine disease: are diseases in ocean ecosystems increasing? PLoS Biology 2 (4): e120 Public Library of Science.

Webb, S.R., G.C. Garman, S.P. McIninch, T.A. Nerad, M.T. Peglar, P.M. Gillevet, and B.L. Brown. 2005. Etiology of ulcerative lesions of Atlantic menhaden (Brevoortia tyrannus) from James River, Virginia. Parasitology Research 97 (5): 358-366.
Whyte, S.K., R.J. Cawthorn, and S.E. McGladdery. 1994. Co-infection of bay scallops Argopecten irradians with Perkinsus karlssoni (Apicomplexa, Perkinsea) and an unidentified coccidian parasite. Diseases of Aquatic Organisms 18 (1): 53-62.

Wilberg, M.J., M.E. Livings, J.S. Barkman, B.T. Morris, and J.M. Robinson. 2011. Overfishing, disease, habitat loss, and potential extirpation of oysters in upper Chesapeake Bay. Marine Ecology Progress Series 436: 131-144.

Zhao, M., D. Behringer, J. Bojko, A. Kough, L. Plough, C. Tavares, A. Aguilar-Perera, O. Reynoso, G. Seepersad, O. Maharaj, M. Sanders, D. Carnales, G. Fabiano, D. Carnevia, M. Freeman, N. Atherley, L. Medero-Hernández, and E. Schott. 2020. Climate and season are associated with prevalence and distribution of trans-hemispheric blue crab reovirus (Callinectes sapidus reovirus 1). Marine Ecology Progress Series 647: 123-133.

Zimmerman, J.L., and S.A. Welsh. 2012. Prevalence of Anguillicoloides crassus and growth variation in migrant yellow-phase American eels of the upper Potomac River drainage. Diseases of Aquatic Organisms 101 (2): 131-137. 